\title{
Media Strategy in Covering Religious Conflicts: A Case Study of Ahmadiyah Conflict in West Java, Indonesia
}

\author{
ENCEP DULWAHAB \\ ACENG ABDULLAH \\ ENI MARYANI \\ Universitas Padjadjaran, Indonesia \\ ASEP SAEFUL MUHTADI \\ UIN Sunan Gunung Djati, Indonesia
}

\begin{abstract}
The Ahmadiyah conflict in Indonesia is often publicised by the Indonesian mass media at local and national level. The media plays an important role in covering conflict and there is a great interest among media and communication researchers to investigate media portrayals of these events. Most studies focused on the role of the media and journalists in the conflict. Very limited study however focused on media approach or analysing media strategies in covering the conflict. This research aims to explore strategies by two newspapers i.e: the Pikiran Rakyat (the biggest newspapers in West Java) and Republika (one the biggest newspapers in Indonesia) in reporting the Ahmadiyah religious conflict in Indonesia. Applying a qualitative approach, using a case study method, this research revealed that both media outlets applied four strategies in covering the Ahmadiyah conflict. These strategies are: (1) Building and maintaining good relations with news sources, which includes people involved in the conflict and witnesses; (2) Establishing a basecamp in which the journalists can focus on covering the conflict for a longer period; (3) Conducting interviews with news informants and making efforts to be accepted by the local people by mingling with the community and showing their neutrality stance; (4) Presenting and maintaining the accuracy of news. The result of this study is expected to contribute to the emerging literature on media and conflict, as well as understanding journalistic practice in covering various religious conflicts in Indonesia and beyond.
\end{abstract}

Keywords: Media, journalist, coverage, conflict, Ahmadiyah religious community.

\section{INTRODUCTION}

Two decades after Indonesia entered the era of reformation, Ahmadiyah, one of the minority religious communities in the country, continues to experience various forms of violence (Hendartyo, 2018) especially from some "hardliner" Islamic groups. Recently, the Ahmadiyah community in Sukabumi, West Java, was conflicted with the surrounding Muslim communities as they were not allowed to rebuild their broken mosque (BBC News Indonesia, 2020). In another conflict, an Islamic "hardliner" group forced the community to destroy their praying facilities in Central Java (Kuwado, 2016).

The Ahmadiyah members or Jamaah Ahmadiyah and many religious scholars believe that they are part of the larger Muslim communities. However, many other Muslim communities and scholars, including the Indonesian Council of Ulama (Majelis Ulama Indonesia: $\mathrm{MUI}$ ), believe that the Ahmadiyah is not part of Islam therefore is considered to be deviant to the religion. The escalation of the Ahmadiyah conflict in Indonesia was intensified after the MUI issued an Islamic ruling or fatwa on the prohibition of Ahmadiyah teaching in Indonesia in 2005 (Noor, Syamsiyatun, \& Banawiratma, 2013). 
It started in 2008, when the Minister of Religion, the Attorney General, and the Minister of Home Affairs of the Republic of Indonesia issued a Joint Decree which focuses on limiting the teaching and activities of the Ahmadiyah community in Indonesia. The initial goal of this decree was to reduce the conflict between the Ahmadiyah and other (majority) Muslim communities including the "hardliners". However, instead of reducing conflict, the decree became another basis for radical Islamic groups to threaten and discriminate against the Ahmadiyah community. In the same year as the decree was published, the community experienced 20 violent attacks from various Islamic groups (CRCS, 2008). Their religious facilities and infrastructure were destroyed. Their mosques and praying activities were also banned.

Compared to other regions in the country, the province of West Java has the highest number of Ahmadiyah conflict cases (CRCS, 2008). After the issuance of the 2008 decree, the conflict between the Ahmadiyah community and "hardliner" Islamic organisations in West Java continued to happen. The latest recorded case happened in Sukabumi, one of districts in West Java in 2020 (Pikiran Rakyat, 2020). From 2011 to 2020, Pikiran Rakyat, the biggest newspaper in West Java and one of the biggest in Indonesia, published at least 14 reports on conflict between the Ahmadiyah and "hardliner" Islamic groups.

The media plays an important role in covering the Ahmadiyah conflict and there is a great interest among them to cover the crisis (Rahmawati \& Anwari, 2013). The conflict has been widely covered not only by West Java based media but also by the national media. The role of the media in the conflict is very critical. Some empirical studies showed that media contribute to creating audience perception towards a conflict (An \& Gower, 2009; Semetko \& Valkenburg, 2000). However, the media may not always report the conflict objectively. Some media are more interested in highlighting controversial issues around the conflict that may trigger further conflict. This kind of coverage is often published by media with ideological ties with groups that are involved in the conflict (Rusmulyadi, 2013).

The important role media plays in covering a conflict, including religious conflict, has created a lot of interest among media and communication researchers. Most studies have focused on the role of the media and journalists in a conflict (Rusmulyadi, 2013; Rahmawati \& Anwari, 2013; An \& Gower, 2009; Semetko \& Valkenburg, 2000). However, very limited studies have focused on journalists' approach or strategies in covering the conflict. A study with this focus would be valuable to provide more insight on how the media deals with various challenges and work under complex conditions to cover and publish news about the conflict. Given this research gap, this article focuses on media strategies in covering religious conflicts, in particular to the Ahmadiyah conflict in West Java, Indonesia.

\section{LITERATURE REVIEW}

\section{Media and Conflict}

There are many studies conducted in different countries concerning the issue of media and conflict. Some of these studies showed that media coverage on a conflict may have a negative impact on the conflict itself. This negative impact relates to the way in which the media covers the conflict. Studies from Carter, Thomas, and Ross (2011) with Marsden and Savigny (2009) found that the media has the ability to set the stage for future conflict by quietly portraying oppositional relations between two conflicting groups. Zillich's study in Germany and Fernandez-Villanueva's study in Spain showed that in reporting conflicts, media tend to exaggerate the conflict event which in turn escalates the conflict instead of solving it (Zillich, Gobbel, Stengel, Maier, \& Ruhrmann, 2011). A study from Milioni, Doudaki, Tsiligiannis and 
Vadratsikas (2015) in Cyprus even found that the media can play a role in reconstructing conflict.

In their study on Nigerian media, Aliyu O. Musa and Neil Ferguson (2013) showed that the media can play a role to escalate a conflict. They observed that in covering conflict, newspapers in Nigeria use terms from a conflicting party and use stereotypical terms towards the other. By doing so, the Nigerian mass media indirectly 'teaches' readers about intolerance and hatred that would make the conflict even worse (Musa \& Ferguson, 2013).

In addition to the above media-focused studies, some other researchers focused their study on the relation between individual journalists and conflict. These studies found that some journalists uphold professional narratives and report 'only facts' and 'reality' in conflict news (Hoxha \& Hanitzsch, 2018). They also reconstruct the intellectual 'reality' by reporting real evidence and examples. However, many journalists also overemphasized the aspect of disputes, drama, and violence of the conflict in their reporting (Tumber, 2009). Other studies showed how journalists systematically exclude voices from certain groups and only rely on "elite" sources (Ersoy, 2010; Manning, 2001). They also rather emphasise the most dramatic aspects of conflict and systematically ignore the factors that caused them, as well as the process of resolution and reconciliation (Wolfsfeld, 2004).

\section{Media Strategy in Covering Conflict}

One of the underlying problems in the way in which media or journalists cover conflict is the usage of war journalism approach in their reportings (Lee \& Maslog, 2005). Lee and Maslog (2005) observed that this approach is widely used by media in covering conflicts in many countries including some Asian countries such as Pakistan, Sri Lanka, the Philippines and Indonesia. One of the characteristics of war journalism is its biased focus on "elite" sources and framing the event in an oppositional position of good and bad (Lee \& Maslog, 2005).

In covering conflict, such as the Ahmadiyah conflict, it is certainly different from covering a war. In covering a conflict, the media has to apply different approaches and methods. Johan Galtung (in Lynch \& McGoldrick, 2005) showed the different approach between conflict coverage and war coverage or between conflict journalism and war journalism. They highlighted four keys to the conflict and war coverage approach that distinguished between the two, as seen in table 1 and table 2 below:

Table 1: Peace/Conflict Journalism

I. PEACE/CONFLICT-ORIENTED

- Explore conflict formation, $x$ parties, y goals, $z$ issues general "win, win" orientation

- Open space, open time; causes and outcomes anywhere, also in history/culture making conflicts transparent

- Giving voice to all parties; empathy, understanding see conflict/war as problem, focus on conflict creativity

- Humanisation of all sides; more so the worse the weapons

- Proactive: prevention before any violence/war occurs

- Focus on invisible effects of violence (trauma and glory, damage to structure/culture)

II. TRUTH-ORIENTED

- Expose untruths on all sides / uncover all cover-ups

III. PEOPLE-ORIENTED

- Focus on suffering all over; on women, aged children, giving voice to voiceless

- Give name to all evil-doers Focus on people peace-makers

IV. SOLUTION ORIENTED

- Peace $=$ non-violence + creativity

- Highlight peace initiatives, also to prevent more war Focus on structure, culture, the peaceful society

Aftermath: resolution, reconstruction, reconciliation 
Table 2: War/Violence Journalism

I. WAR/VIOLENCE ORIENTED

- Focus on conflict arena, 2 parties, 1 goal (win), war general zero-sum orientation

- Closed space, closed time; causes and exits in arena, who threw the first stone

- Making wars opaque/secret

- "us-them" journalism, propaganda, voice, for "us"

- See "them" as the problem, focus on who prevails in war

- Dehumanisation of "them"; more so the worse the weapon

- Reactive: waiting for violence before reporting

- Focus only on visible effect of violence (killed, wounded and material damage)

II. PROPAGANDA-ORIENTED

- Expose "their" untruths / help "our" coverups/lies

III. ELITE ORIENTATED

- Focus on "our" suffering; on able-bodied elite males, being their mouth-piece

- Give name to their evil-doers focus on elite peace-makers

IV. VICTORY ORIENTATED

- Peace $=$ victory + ceasefire

- Conceal peace-initiative, before victory is at hand Focus on treaty, institution, the controlled society

- Leaving for another war, return if the old flares up again

Table 1 and Table 2 shows the clear differences between conflict and war journalism. The comparison above also implies that using a war journalism approach in covering various kinds of conflict may lead to negative impact. In addition to Galtung's model, there are also some other strategies that can be applied by media and journalists in covering a conflict. These strategies were also supported by field-based research findings including those from Indonesia. Anto and Pardede (2007) suggested that in covering a conflict, journalists should meet at least two basic requirements. Firstly, they have to know the nature of the conflict and secondly, they should recognise the structures of conflicts to be reported (Anto \& Pardede, 2007). Siebert and Baumann (1990) added that a journalist who covers a conflict must have the principle of opposing the conflict, warn of the falling victim during the conflict, and make specific suggestions in their conflict coverage. Furthermore, Peter du Toit (2015) argued that a journalist must also inform the conflict to the reader with a detailed event and consider various factors in its coverage. In addition, Hoiby and Ottosen (2017) emphasised that a journalist must be able to get access from both conflicting parties. Without access to conflict areas, the news created by journalists cannot be objective. The difficulty in accessing conflict areas can lead to biased coverage and have an impact on the decline in journalistic quality (Hoiby \& Ottosen, 2017).

In addition to strategies and standards, media also have to apply some ethics in covering conflict. There are several ethics in covering conflict including field-based reporting (from conflict areas), taking into account the broader implications of news, do not limit judgments about the conflict to the visible effect, avoid focusing on the differences between the two conflicting parties, be careful in using words reporting violence, and be careful in citing sources (Syahputra, 2006). Journalists also have to maintain the accuracy of the data because it is a very important factor. As it was said by Joseph Pulitzer, accuracy is a "fixed price" in any news (Anto \& Pardede, 2007). Furthermore, in covering conflict, journalists have to maintain their objectivity and professionalism (Vandevoordt, 2015) including professionalism in using language in crafting news based on accurate data. Language capacity is very important as mass media can use language (word choice) in creating harmony (Wibowo, 2018). 
Galtung and other experts agreed that in covering conflict, media must be able to reduce and resolve the conflict (Galtung in Lynch \& McGoldrick, 2005; Wilson \& Ibrahim, 2018). In order to do so, for instance, editors and journalists can be trained to use appropriate media language and serve as peace communicators. They should also be proactive in presenting various dimensions of conflict. When they have identified increasing symptoms of ethnic dispute, terrorism, and rebellions, editors and journalists should perform as supplier of peace reports through their coverage (Wilson \& Ibrahim, 2018). This way, the media can help reduce intolerance and communal conflict (Tim AJI Jakarta, 2014).

\section{METHODOLOGY}

This research applied a qualitative approach, using a case study method. Yin (2003) stated that a case study focuses on contemporary phenomena in the context of real life and proposes questions regarding the "how" or the "why". In this case, the conflict between the Ahmadiyah and "hardliner" Islamic organisations is a contemporary phenomenon (continues to occur) and is an interesting event to be investigated. The conflict has attracted public attention, including governments at local and national level. In addition, the Ahmadiyah conflict itself is complicated and related to broader religious diversity issues in Indonesian society. As Indonesia is a country that has a high heterogeneity population in terms of religion and culture, it is always susceptible to various forms of conflicts.

Data collection for this study was carried out using in-depth interview technique on 10 informants who are directly involved in the on-site reporting and producing news on the Ahmadiyah conflict. There were three main questions asked to the informants: (1) how do you approach and interview the news sources? (2) how do you cover conflict locations? and (3) how do you produce conflict news?

These interviews were conducted on journalists of the Pikiran Rakyat (the biggest West Java based newspaper) and Republika (One the biggest national newspapers). The two media are selected because they continually report news on the Ahmadiyah conflict. In addition, Pikiran Rakyat was particularly selected because it is a West Java based news media in which most of the Ahmadiyah conflict occurred. Both the media also have a broad and loyal reader in West Java and across the country. In 2016, Nielsen Media Research (in Putra, 2018) estimated that the total daily circulation of Pikiran Rakyat reached 169,000 . While for Republika, Jannatin (2020) reported that its daily circulation reached 80,000.

\section{FINDINGS AND INTERPRETATION}

Based on the data obtained from in-depth interviews, it is found that there are four strategies applied by media and journalists in covering the Ahmadiyah conflict. First, building and maintaining close relations with various news sources especially with those involved in the conflict. Second, establishing a basecamp for journalists. Third, mingling with people in conflict areas and being neutral. Fourth emphasizing the accuracy and details in gathering facts from the conflict area.

\section{Build and Maintain Close Relations with News Sources}

News source is one of the most important aspects in creating the news. Without a news source, journalists will find it is difficult to obtain facts and data, therefore making it difficult to make news reports. Journalists in Pikiran Rakyat and Republika are aware of this. However, they also understand that being close to conflicting parties, in this case the Ahmadiyyah 
community and some "hardliner" Islamic organisations, is not always easy. Yet, conflicting parties are the main news sources. Other news sources include people or residents who live in the surrounding conflict areas, relevant government agencies at local and national level, and other relevant stakeholders. The journalist, therefore, can start to build close relations with these news sources, while at the same time approaching the conflicting parties. Pikiran Rakyat and Republika journalists build and maintain relations with news sources, including members of the communities by, among others, taking part in the community events, making friends, and introducing themselves as journalists.

Being close to and having trusted relations with various groups in the communities is beneficial for the journalists. It would make it easier and faster for journalists to get information from the field if another (or sequel) of conflict occurs. The residents or members of communities will contact journalists directly when they hear, see, or feel the conflict in their neighbourhood. According to one informant, "The first time I got information about the Ahmadiyah conflict was initially from the residents, who happened to know that I was a journalist. They told me there was a conflict between the Ahmadiyah and Islamic organisations in their neighbourhood" (R1). Knowing the conflict directly from the witness at the field, make journalists such as R1 get information faster and more accurately.

Citizens or officers at government offices who inform journalists about Ahmadiyah conflict are considered very important informants. They gave information about the conflict voluntarily to Pikiran Rakyat dan Republika journalists because the informants have close relations with the journalists. The closeness of the journalists with the informants is established because the journalists regularly work and hang out in the area where the informants live or work. During this field work in their coverage area, the journalists not only focus on finding information for specific news, but also communicate and interact with the local people. One informant (R2) shared his experience about the time he got information about a conflict which came from the people who live in his coverage area. At that time, the journalist was actually not officially assigned to cover the conflict. However, because he received this new information from the field, he informed his editors who then sent him to cover the conflict. "When I heard from the surrounding community that there was an Ahmadiyah conflict and it happened to be close to the assignment of my coverage area, I took the initiative to cover it, of course with permission from the office," (R2).

In addition to maintaining good relations with news sources, the journalists also always follow developments of conflicts by regularly reading news from other newspapers and watching television. "I also continue to follow the (conflict) development by monitoring the news from other media, so I know what other media are reporting," (R1).

\section{Build a Basecamp}

Religious conflict is a complicated and sensitive issue, and tends to prolong for quite some time. Therefore, to be able to get comprehensive information about it, Pikiran Rakyat and Republika have to make better preparations before covering an event.

Once a journalist gets initial information about an Ahmadiyah conflict event from a trusted news source, the journalist will report it to the editorial department. "When I receive information about an Ahmadiyah conflict event from a friend, who happened to live near the conflict area, I will report it to the office" (R3). Another informant similarly said, "I do not dare to cover it (the conflict) immediately. I will inform the office and wait for further instructions. Because there might be other journalists who have been assigned by the office 
to cover the conflict. The conflict area was also quite far from where I was. So, I waited for further orders from the office" (R4).

After receiving an initial report from a journalist about a conflict, the editorial team will discuss appropriate action to take next. The editors would usually verify the information before making any decision. If the information is correct, the editorial team will hold a meeting to arrange the next steps to be taken. They will also identify some important and interesting issues surrounding the event. Having established a list of topics to cover, the editor will determine who to be assigned to cover the conflict. An informant who served as one of the editors at Pikiran Rakyat said, "After the conflict is confirmed, we then determine the appropriate journalists to cover it. Not all journalist can cover the (Ahmadiyah) conflict. They must have sufficient knowledge about the Ahmadiyah, and the challenge (they may face) in the conflict area" (E1).

When the conflict is a large-scale or an extraordinary one, the editor will assign not just one journalist, but a team of reporters to cover the conflict. The media will drop the team near the conflict area and build a base camp in which the team can intensively work on the event. The location of the base camp must be strategic, close access to transportation and other necessary facilities such as the Internet or telephone facilities. In this regard, an informant said, "We first study the case and the issue. If the issue is small, we ask reporters who cover conflict areas (regularly working in that area) to cover it. But after we know the exact location of the conflict, the issues and cases are large, and based on the results of the editorial meeting, we determine to have a base camp that is close to the location of the conflict is and we send the team near the conflict location to make it easier for them to work" (E2).

The base camp functions as a place for meeting, coordination, rest, and sharing tasks among the journalists. To address journalist fatigue, they would be working on rotation. Normally, one or two journalists will be on the field per day and he or she will return to the base camp to write news once they have obtained the data needed. Once the first rotation of journalist(s) finished their job, another set of journalist(s) will be sent to the field to monitor the progress of the conflict. "After they are at the location, we cover the conflict in rotation. During the day (we) send a reporter, at night he/she returns...to immediately make the report" (E2).

\section{Blend with Society and Being Neutral}

Having established a base camp, editors will start to assign journalists to the field. The chief editor would ask journalists to speak to the local residents, the Ahmadiyah groups, local officials, and fellow journalists from other media. An informant shared his experience when he was assigned in the conflict area, "In the field when covering conflicts, I met variety of people, including journalists, and we help one another. When the conflict is large... on an international scale, I usually meet with journalists from other media from different countries" (R4).

In the field, journalists who cover the Ahmadiyah conflict need to introduce themselves to the local people they meet. The journalists also have to convince the people that they will not take actions that will have negative impact to the local people. Journalists also have to ensure the people that their position is neutral. The presence of journalists aims to calm the people who are impacted by conflict and help reduce and reconcile conflicts. An 
Informant (E2) said, "In the field, we introduce our identities and convince them that we are indeed neutral and will help solve the problem".

There are several advantages when journalists mingle with local residents and impacted individuals. Firstly, it will make it relatively easy for journalists to get information and sources to interview. In addition, when the local people (including conflicting parties) are convinced that the journalists are in a neutral position, they will feel less threatened and would share information on what they see, hear and feel to the journalist. It can be seen in the statement of one of the informants (R4), "People are relatively open if they know that we are journalists. (Their attitude) is different when they are around the police or the TNI (army), they tend to be quiet and there is a kind of concern".

In Pikiran Rakyat and Republika, journalists are not asked to directly interview government officials before getting data and facts from the field. Because the media are afraid that data and facts will be biased when they rely on government sources. An informant (E2) said, "In the field, journalists are asked to interview local people. Do not always rely on the government officers". Another informant (R3) stated, "Government officials will ask their staff (to answer the questions). So the information is received from a second or third source and not directly from the main source".

\section{Presenting Evidence Accurately}

Another strategy in covering the Ahmadiyah conflict is that journalists must present strong and accurate data and evidence. According to R3, "If facts are fabricated, it is very dangerous for the reader. The news will be a lie and if the reader knows we are lying it is the same as killing our careers". To be able to get accurate evidence or data, journalists have to get information directly from the news sources in the field. As one informant said, "We cannot ask about the evidence and data from other journalists. It can be different if we get data (directly) in the field with the data that we get from others. Although this method is easy to do, the feel would be different especially for conflict coverage" (R1).

In addition to interviewing both conflicting parties, journalists in Pikiran Rakyat and Republika must include photographs in their reports. "Journalists are also provided with camera to photograph conflict locations, and to add information so that readers believe in the truth of conflict events" (E1). This implies that journalists are required to have skills in photography. If a journalist does not have the skills to take pictures, he or she may lose the advantage to provide stronger evidence. "The number of photographers is limited. But now it is easy to take pictures because the camera is more mobile, especially phones that can be used to take photos" (R1).

\section{DISCUSSION}

The four strategies above are critical to ensure that the media could get access to the conflict area, gather factual data, and report the conflict news comprehensively on the religious conflict. The first strategy is to build and maintain relations with news sources in conflict areas. Having good relations with news sources will ensure journalists have access to information from the news sources. Without access to news sources in conflict areas, the produced news would not be in accordance with the actual events, therefore the quality of the news cannot be trusted (Hoiby \& Ottosen, 2015). According to Kusumaningrat and Kusumaningrat (2009), in order to get exclusive news, the media need to have informants (liaison) who notifies the media if there is an important event or new development that is not yet known to other journalists. Building relations with local people is one of the ways to find 
these informants. They may come from both conflicting parties or from a witness who lives near or within the conflict area. Furthermore, having good relations with local people (and public in general) is not only beneficial for journalists or the media but also for the public. Journalists need to get data on conflict events, while people who experience the conflict or live in the conflict area want their voice to be heard and known by a wider public and by government officials.

Without direct access to news sources in conflict areas the news coverage may lead to worsening conflict. Musa and Yusha'u (2013) in their study about Boko Haram conflict found some problems when journalists were not entirely based in conflict-affected areas. The results of their coverage led to misunderstandings and incorrect reporting of crises. This type of reporting may also lead to accidental polarisation of conflicts, due to many assumptions and stereotypes (Musa \& Yusha'u, 2013).

Once the journalists have access to the conflict area and build relations with local people, they can start to build base camps in which they can focus on covering the conflict for a longer period. Building a base camp could help journalists prepare and plan by making a checklist about what should be done in the field such as sharing a board sheet with a list of sources to be contacted (Kusumaningrat \& Kusumaningrat, 2009).

The third strategy is to mingle with communities and be neutral. The ability of the media to play the role of the fourth estate in times of war and crisis would depend on the ability of journalists to cover the conflict objectively (Nohrstedt \& Ottosen, 2017; Anto \& Pardede, 2007). Part of this is the ability to immerse themselves with the communities and being neutral. It is indeed not easy for journalists to cover conflict, because there are so many risks that journalists may face when doing their work in the conflict area (Nohrstedt \& Ottosen, 2014).

Journalists can mingle with people in the conflict areas by applying what Wibawa (2018) calls mutualist relations. Overall, he argued that there are five patterns of communication between journalists and news sources which include mutualism, parasitism, commensalism, epigonism, and neutralism. Among these five forms of patterns, journalists can develop mutualist and neutral relations. It is not easy for media and journalists to be neutral in their reporting, especially in reporting conflict. It is because reporting conflict is often influenced by several factors, including external factors (Shoemaker \& Reese, 2013) especially the domination of government (Bennett, Lawrence \& Livingston, 2007; Robinson, Goddard \& Murray, 2009). Journalists can anticipate this by prioritising news sources from the local people or those who experience the conflicts (e.g. victims).

A journalist who mingles with the community during his field work in a conflict area also means that a journalist dedicates himself, pays special attention to his work, and looks for problem solvers in the field (Tumber \& Webster, 2006). To maintain the neutrality, media and journalists could practice Johan Galtung's approach in covering conflict (in Lynch \& McGoldrick, 2005) which include prioritising the news on conflicting communities and not government officials.

The fourth strategy is presenting accurate information. The most important part in news coverage to ensure the accuracy of the news is gathering facts and data directly from the field. It is also important for journalists to not take data only from one conflicting party (e.g. from the "hardliner" Islamic group) or only from government officials. In addition, in covering the Ahmadiyah conflict it would also be better for the journalist to do additional research by reading some documentation and other additional relevant material to support 
the facts from the field (Kusumaningrat \& Kusumaningrat, 2009). The materials may include the history of Ahmadiyah, the missions or goals of the establishment of Ahmadiyah, and the orientation of Ahmadiyah activities. The knowledge about Ahmadiyah will help journalists in carrying out their duties as they have better understanding of the conflict context and therefore will help them to present accurate facts in their news. In addition to reading and reviewing some relevant materials, to keep updated with the conflict from various perspective, journalist can also regularly follow developments in social media and other media (Hoxha \& Hanitzsch, 2018).

\section{CONCLUSION}

In covering religious conflict, Indonesian mass media applied four strategies which include (1) build and maintain good relations with news source or informant who experience, witness, or know about the conflict; (2) build basecamp in which journalists can focus on covering conflict; (3) in order to easily obtain information, conduct interviews with informants, and be accepted by local people, the journalists have to mingle with the community and show their neutrality; (4) write a report or news that is carefully crafted based on accurate facts and data from the field. To get accurate facts and data, journalists must go directly to the location of the conflict and not just listen or read from secondary sources. By directly covering the conflict in the field, they could also feel the atmosphere of conflict on the ground.

The four strategies above seem to be applicable in all types of news events, not only in covering conflict events. However, the detailed steps or activities in each strategy is quite different from covering other news events. The differences are especially related to the sensitive and complicated nature of a religious conflict such as the Ahmadiyah conflict. A little misstep in presenting the news may lead to dangerous effects for the conflict. In other words, covering a conflict has to be carried out very carefully. However, the four strategies above are not without limitation. The problem with the strategies applied by Pikiran Rakyat and Republika in covering and reporting the Ahmadiyah conflict is that they do not have specific strategies to reduce the conflict or promote reconciliation via their reporting. The two media could have played a bigger role in resolving conflicts, especially the Ahmadiyah conflict in West Java and Indonesia.

\section{BIODATA}

Encep Dulwahab is a lecturer in the Journalism Science Study Program, State Islamic University, Bandung, Indonesia. The focus of his study is on mass communication and peaceful journalism. Email: encep17001@mail.unpad.ac.id

Aceng Abdullah, is the head of the Film Study Program at Padjadjaran University in Bandung, Indonesia, focusing his studies on media, film and corruption communication. Email: aceng.abdullah@unpad.ac.id

Eni Maryani, is the head of the center of media studies at the Faculty of Communication, Padjadjaran University, Bandung, Indonesia, focusing on gender, media studies, and critical studies. Email: eni.maryani@unpad.ac.id

Asep Saeful Muhtadi is a professor of communication at Sunan Gunung Djati State Islamic University in Bandung, Indonesia, focusing her studies on political communication. Email: mangsamuh@gmail.com 


\section{REFERENCES}

An, S. K., \& Gower, K. K. (2009). How do the news media frame crises? A content analysis of crisis news coverage. Public Relations Review, 35(2), 107-112. https://doi.org/dzh5m9

Anto, J., \& Pardede, P. (Eds). (2007). Meretas jurnalisme damai di Aceh: Kisah reintegrasi damai dari lapangan. Jakarta: Yayasan Obor Indonesia.

BBC News Indonesia. (2020, March 2). Jemaah Ahmadiyah Sukabumi: Mengadu ke Komnas HAM, "Kami tidak boleh perbaiki masjid kami yang sudah jadi sarang kelelawar". https://www.bbc.com/indonesia/indonesia-51670914

Bennett, W. L., Lawrence, R. G., \& Livingston, S. (2007). When the press fails: political power and the news media from Iraq to Katrina. Chicago: University of Chicago Press.

Carter, D. L., Thomas, R. J., \& Ross, S. D. (2011). You are not a friend: Media conflict in times of peace. Journalism Studies, 12(4), 456-473. https://doi.org/dx9hif

CRCS (Center for Religious and Cross-cultural Studies). (2008). Laporan tahunan kehidupan beragama di Indonesia 2008. https://crcs.ugm.ac.id/annual-reports/

du Toit, P. (2015). Reporting atrocities: A Toolbox for journalists covering violent conflict and atrocities. USAID: United States Agency for International Development.

Ersoy, M. (2010). Peace journalism and news coverage on the Cyprus conflict. The Muslim World, 100(1), 78-99. https://doi.org/10.1111/j.1478-1913.2009.01303.x

Hendartyo, M. (2018). Ahmadiyah disebut kerap alami kekerasan berbasis agama sejak 1998. Tempo. https://nasional.tempo.co/read/1091172/ahmadiyah-disebut-kerap-alamikekerasan-berbasis-agama-sejak-1998

Hoiby, M., \& Ottosen, R. (2017). Journalism under pressure in conflict zone: A Study of journalists and editor in seven countries. Media, War \& Conflict, 12(1), 69-86.

Hoxha, A., \& Hanitzsch, T. (2018). How conflict news comes into being: Reconstructing 'reality' through telling stories. Media, War \& Conflict, 11(1), 46-64. https://doi.org/10.1177/1750635217727313

Jannatin, S. M. (2020). Laporan praktik kerja lapangan pada PT Republika Mandiri. Jakarta: Program Studi Manajemen Fakultas Ekonomi Universitas Negeri Jakarta.

Kusumaningrat, H., \& Kusumaningrat, P. (2009). Jurnalistik: Teori dan praktik. Bandung: PT Remaja Rosdakarya.

Kuwado, F. J. (2016, May 23). Masjid Ahmadiyah di kendal dirusak massa tak dikenal. Kompas. https://nasional.kompas.com/read/2016/05/23/11224741/masjid.ahmadiyah.di.ken dal.dirusak.massa.tak.dikenal

Lee, S. T., \& Maslog, C. C. (2005). War or peace journalism? Asian newspaper coverage of conflicts. Journal of Communication, 55(2), 311-329.

Lynch, J., \& McGoldrick, A. (2005). Peace journalism. London: Hawthorn Press.

Manning, P. (2001). News and news sources: A critical introduction. SAGE Publications.

Marsden, L., \& Savigny, H. (2009). Towards a theorisation of the link between media, religion and conflict. In, Media, Religion and Conflict. Taylor.

Milioni, D. L., Doudaki, V., Tsiligiannis, P., \& Vadratsikas, K. (2015). Conflict as news and news as conflict: A Multidimensional content analysis of TV news in Cyprus. International Journal of Communication (IJoC), 9, 2391-2411.

Musa, A. O., \& Ferguson, N. (2013). Enemy framing and the politics of reporting religious conflicts in the Nigerian press. Media, War and Conflict Journal, 6(1), 7-20. 
Musa, A. O. \& Yusha'u, M. J. (2013). Conflict reporting and parachute journalism in Africa: A study of CNN and Al Jazeera's coverage of the Boko Haram insurgency. Journal of Arab \& Muslim Media Research (JAMMR), 6(2\&3), 251-267.

Nohrstedt, S. A., \& Ottosen, R. (2014). New wars, new media and new war journalism: Professional and legal challenges in conflict reporting. Gothenburg: Nordicom.

Nohrstedt, S. A., \& Ottosen, R. (2017). Sustainable war journalism and international public law. In P. Berglez, U. Olausson, \& M. Ots (Eds.), What is sustainable journalism?: Integrating the environmental, social, and economic challenges of journalism. Peter Lang Publication.

Noor, N. M., Syamsiyatun, S., \& Banawiratma, J. B. (2013). Ahmadiyah, conflicts, and violence in contemporary Indonesia. IJIMS: Indonesian Journal of Islam and Muslim Societies, 3(1), 1-30. https://doi.org/10.18326/ijims.v3i1.1-30

Putra, I. C. (2018). Pengaruh brand image dan brand trust terhadap brand loyalty PT Pikiran Rakyat Bandung pada generasi millenials di Bandung [Undergraduate thesis, Universitas Katolik Parahyangan, Bandung]. UNPAR Institutional Repository. https://repository.unpar.ac.id/handle/123456789/8263

Rahmawati, E., \& Anwari, T. (2013). Menyikapi pemberitaan seputar agama. In A. Armando, A. Junaidi, B. Kurniawan, D. Awigra, D. Candraningrum, ..., U. Kansong (Eds.), Jurnalisme keberagaman: Sebuah panduan peliputan. Jakarta: HIVOS dan SEJUK Press.

Robinson, P., Goddard, P., \& Murray, C. (2009). Testing models of media performance in wartime: U.K. TV news and the 2003 invasion of Iraq. Journal of Communication, 59(3), 534-563.

Rusmulyadi. (2013). Framing media Islam online atas konflik keagamaan di Indonesia. Jurnal Komunikasi Islam, 3(1), 48-75.

Semetko, H. A., \& Valkenburg, P. M. (2000). Framing European politics: A content analysis of press and television news. Journal of Communication, 50(2), 93-109. https://doi.org/10.1111/i.1460-2466.2000.tb02843.x

Shoemaker, P. J., \& Reese, S. D. (2013). Mediating the message in the 21st century: A media sociology perspective. New York: Routledge.

Siebert, H., \& Baumann, M. (1990). Journalists as mediator. Rhodes Journalism Review, 42-46.

Syahputra, I. (2006). Jurnalisme damai: Meretas ideologi peliputan di area konflik. Yogyakarta: P-Idea.

Tim AJI Jakarta. (2014). Pedoman perilaku jurnalis (Ed. by J. Jamaluddin). Jakarta: Aliansi Jurnalis Independen Jakarta.

Tumber, H. (2009). Covering war and peace. In K. W. Jorgensen, \& T. Hanitzsch (Eds.), The handbook of journalism studies. New York: Madison Ave.

Vandevoordt, R. (2015). Why journalists covered Syria the way they did: On the role of economic, social and cultural capital. Journalism, 18(5), 609-625.

Wibawa, D. (2018). Communication pattern of Indonesian journalists with news source in the internet era. Jurnal Komunikasi: Malaysian Journal of Communication, 34(1), 316-329.

Wibowo, A. H. (2018). The language of media supporting peace journalism. Jurnal Komunikasi: Malaysian Journal of Communication, 34(3), 349-360.

Wilson, S., \& Ibrahim, F. (2018). Diplomacy in reporting: The Sulu conflict in East Borneo. Jurnal Komunikasi: Malaysian Journal of Communication, 34(3), 245-257.

Wolfsfeld, G. (2004). Media and the path to peace. Cambridge University Press.

Yin, R. K. (2003). Case study research: Design and methods (3rd ed.). Sage Publication. 
Zillich, A. F., Gobbel, R., Stengel, K., Maier, M., \& Ruhrmann, G. (2011). Proactive crisis communication? News coverage of international conflicts in German print and broadcasting media. Media, War \& Conflict, 4(3), 251-261. https://doi.org/fzgh3g 